\title{
Hubungan Antara Pelatihan, Kepuasan Kerja dan Kinerja Tempat Kerja pada Organisasi Pelayanan Publik Studi pada Satuan Polisi Pamong Praja dan Pemadam Kebakaran Kabupaten Semarang
}

\author{
Firdania Rarastiti Arisadewi ${ }^{\text {a* }}$ \\ ${ }^{a}$ Dinas Satuan Polisi Pamong Praja dan Pemadam Kebakaran Kabupaten Semarang, Jawa Timur, Indonesia
}

\section{INFORMASI ARTIKEL}

\section{Article history:}

Dikirim tanggal: 01 November 2020

Revisi pertama tanggal: 21 Agustus 2020

Diterima tanggal: 24 Agustus 2020

Tersedia online tanggal: 25 Agustus 2020

Keywords: trainning, work satisfaction, workplace performance, Kabupaten Semarang

\begin{abstract}
Human resources in an organization is an important and influential aspect in the organization's activities and productivity. Good human resources will produce good employee performance which will then have an impact on producing good workplace performance. The purpose of this study was to determine whether training and job satisfaction affect workplace performance at the Civil Service Police Unit and Semarang Fire Department. The sampling technique in this study used simple random sampling, where 126 people were taken from the entire population. The research method uses multiple linear regression analysis, $t$ test, $F$ test and path analysis. The results showed that training had no positive and significant effect on job satisfaction, training had no positive and significant effect on workplace performance and job satisfaction had a positive and significant effect on workplace performance. With the path analtsis it is known that the job satisfaction variable does not meet the requirements to be an interverning variable.
\end{abstract}

\section{INTISARI}

Sumber daya manusia dalam suatu organisasi merupakan aspek penting dan berpengaruh dalam produktivitas dan aktivitas organisasi. Sumber daya manusia dalam organisasi yang baik akan menghasilkan kinerja pegawai yang juga baik dan kemudian akan berdampak menghasilkan kinerja tempat kerja yang baik. Tujuan dari penelitian ini adalah untuk mengetahui apakah variabel pelatihan dan variabel kepuasan kerja memiliki hubungan terhadap variabel kinerja tempat kerja pada Dinas Satuan Polisi Pamong Praja dan Pemadam Kebakaran Kabupaten Semarang.Teknik yang digunakan untuk pengambilan sampel dalam penelitian ini menggunakan simple random sampling, dimana dari seluruh populasi diambil sampel sebanyak 126 orang. Metode penelitian menggunakan analisis regresi liniar berganda, uji t, uji F dan Path Analysis. Hasil penelitian diperoleh bahwa pelatihan tidak memiliki hubungan positif dan signifikan terhadap kepuasan kerja, pelatihan tidak memiliki hubungan positif dan signifikan tterhadap kinerja tempat kerja dan kepuasan keja memiliki hubungan positif dan signifikan terhadap kinerja tempat kerja. Dengan Path Anaysisl diketahui variabel kepuasan kerja memenuhi syarat menjadi variabel interverning. 


\section{Pendahuluan}

Globalisasi dan perkembangan teknologi yang pesat menjadikan suatu organisasi harus dapat berkembang dan memenuhi tuntutan yang ada agar setiap kegiatan, hasil dan pelayanan yang diberikan sesuai denegan tuntutan yang ada. Terutama pada organisasi sektor publik yang memberikan pelayanan kepada masyarakat secara langsung dan dituntut untuk selalu berkembang dan menyesuaikan dengan kebutuhan masyarakat. Faktorfaktor yang dapat meningkatkan kualitas output dalam suatu organisasi antara lain adalah sumber daya manusia, modal dan teknologi. Sumber daya yang sangat penting diantara sumber daya lainnya adalah sumber daya manusia, karena secanggih apapun teknologi yang digunakan dan dimiliki oleh organisasi tidak akan dapat berdaya guna jika tidak didukung oleh sumber daya manusia yang handal.

Salah satu upaya yang dilakukan untuk meningkatkan kompetensi sumber daya manusia agar memiliki keunggulan kompetitif adalah pelatihan. Pelatihan menurut Bernadin \& Russel dalam Gomes (2000, p.197) menyatakan bahwa pelatihan adalah setiap usaha untuk memperbaiki kinerja pekerja tertentu yang sedang menjadi tanggung jawabnya atau satu pekerjaan yang ada kaitannya dengan pekerjaannya. Penelitian yang dilakukan oleh Ahmad \& Schroeder, (2003); Gelade \& Ivery (2003); Faems et al. (2005) bahwa pelatihan tidak memiliki efek langsung pada kinerja, tetapi efek tidak langsung dengan meningkatkan kinerja karyawan dan hasil organisasi lainnya. Menurut Petty et al. (1984) pelatihan dapat memiliki efek tidak langsung pada kinerja jika meningkatkan kepuasan kerja misalnya membuat karyawan lebih merasa dihargai dan lebih mudah melakukan pekerjaan.

Paradigma New Public Management yang memberikan pandangan baru mengenai modernisasi administrasi publik yang menurut Setiyono \& Admojo (2014, p.5) New Public Management (NPM) adalah sebuah paradigma alternatif yang mulai mennggantikan model administrasi publik tradisional, sehingga menjadi administrasi publik yang lebih efisien, efektif dan lebih mengakomudasi pasar. Penerapan New Public Management (NPM) seringkali dipandang sebagai bentuk reformasi atau modernisasi manajemen dan administrasi publik yang lebih mendorong sistem demokrasi. Hal ini menjadikan organisasi sektor publik dapat mengadopsi prinsip-prinsip dan nilai-nilai yang ada pada organisasi sektor privat. Seperti memperhatikan kepuasan kerja karyawan yang menurut beberapa penelitian hubungan pada kinerja.

Dalam tiga tahun terakhir Kemenpan RB selalu mengadakan Sistem Akuntabilitas Kinerja Instansi Pemerintah (SAKIP) Awards dimana Kemenpan RB memberikan rapor dan penilaian terhadap semua kabupaten dan kota yang ada di Indonesia, setiap kabupaten dan kota tersebut akan mendapat predikat sesuai dengan hasil akhir dari evaluasi SAKIP yang dilakukan oleh Kemenpan RB. Untuk kabupaten dan kota yang memperoleh nilai yang masuk kedalam range nilai tertinggi akan mendapat predikat AA, yang kemudian untuk range nilai dibawahnya adalah $\mathrm{A}, \mathrm{BB}, \mathrm{B}, \mathrm{CC}, \mathrm{C}$, dan D. Untuk kabupaten dan kota yang memperoleh predikat A, BB, B akan mendapatkan penghargaan dari Kemenpan RB. Tinggi dan rendahnya penilaian SAKIP dinilai dari seberapa jauh kinerja OPD menyesuaikan dengan visi misi bupati dan wakil bupati. Kabupaten Semarang merupakan salah satu kabupaten yang dalam tiga tahun terakhir belum merasakan memperoleh SAKIP Awards, berbeda dengan Kota Solo, Salatiga, Jepara, dan Kota Semarang yang memperoleh SAKIP Awards dan mengalami kenaikan penilaian.

Menurut Informasi dari Ibu Elis, salah satu staff Bagian Perencanaan dan Keuangan di Satuan Polisi Pamong Praja dan Pemadam Kebakaran Kabupaten Semarang (SATPOL PP dan Damkar); salah satu kelemahan Kabupaten Semarang dalam menyusun Laporan SAKIP adalah seringkali beberapa organisasi perangkat daerah (OPD) tidak dapat menyelesaikan laporan SAKIP tepat waktu. Salah satunya, yaitu OPD SATPOL PP dan Damkar. Bu Elis juga menuturkan salah satu yang menjadi alasan OPD SATPOL PP dan Damkar Kabupaten Semarang sering terlambat melakukan laporan SAKIP karena hanya beberapa karyawan yang dapat mengoperasikan komputer secara baik padahal untuk jumlah pegawai sudah cukup banyak, sehingga ketika dihadapkan dengan semua hal yang berbasis sistem dan electronic government seringkali pekerjaan tersendat dan tidak dapat selesai tepat waktu.

Menurut Bu Elis, di OPD Satpol PP dan Damkar Kabupaten Semarang sudah seringkali diadakan pelatihan baik internal maupun eksternal yang bertujuan untuk meningkatkan kapasitas dan kemampuan pegawai agar dapat meningkatkan kinerja dan mengikuti perkembangan zaman. Namun tidak semua pegawai memiliki kesempatan yang sama untuk mengikuti pelatihan, sehingga kemungkinan akan munculnya kepuasan kerja dan kepercayaan diri yang berbeda dalam pekerjaan yang memungkinkan munculnya kesenjangan kinerja antar individu yang akan berimbas pada kinerja organisasi atau kinerja tempat kerja.

Menilik dari beberapa penelitian yang sudah dilakukan dan masalah-masalah yang muncul di Satuan Polisi Pamong Praja dan Pemadaam Kebakaran Kabupaten Semarang penulis ingin membuktikan benar hubungan pelatihan terhadap kinerja dengan kepuasan kerja sebagai variabel interverning. 


\section{Teori}

\subsection{Pelatihan}

Menurut Bartol dalam Wiludjeng (2007, p.131), mengungkapkan pelatihan dan pengembangan merupakan suatu usaha perencanaan untuk menfasilitasi karyawan mempelajari tingkah laku yang berhubungan dengan pekerjaannya yang bertujuan untuk meningkatkan kinerja karyawan. Bernadin \& Russell dalam Gomes (2000, p.197) menyatakan bahwa pelatihan adalah setiap usaha untuk memperbaiki kinerja pekerja pada pekerjaan tertentu yang sedang menjadi tanggung jawabnya, atau suatu pekerjaan yang ada kaitannya dengan pekerjaannya. Menurut Rivai \& Sagala (2011, p.217), adapun maanfaat pelatihan untuk karyawan adalah:

a) Memberi sokongan kemampuan kepada karyawan dalam menhasilkan suatu keputusan dan pemecahan masalah agar lebih efektif;

b) Dengan pelatihan dan pengembangan, variabel pengenalan, pencapaian prestasi, pertumbuhan, tanggung jawab dan kemajuan dapat diinternalisasi dan dilaksanakan;

c) Membantu untuk mencapai pengembangan diri dan mendorong timbulnya rasa percaya diri;

d) Meminimalisir stress, frustasi, tekanan, dan konflik pada karyawan;

e) Memberikan informasi tentang meningkatnya pengetahuan kepemimpinan, sikap dan ketrampilan komunikasi;

f) Meningkatkan penngakuan dan kepuasan kerja;

g) Membantu karyawan mencapai tujuan pribadi sementara meningkatkan keterampilan interaksi;

h) Memenuhi kebutuhan pelatihan dan personal peserta;

i) Memberikan jalan dan nasehat untuk pertumbuhan masa depan;

j) Membangun rasa pertumbuhan dalam pelatihan;

k) Membantu dalam pengembangan keterampilan mendengar, menulis dan bicara dengan mengikuti latihan; dan

1) Membantu meminimalisir rasa takut untuk menerima dan melaksanakan tugas baru.

Penelitian oleh Petty et al. (1984) menunjukan bahwa pelatihan dapat memberikan efek tidak langsung pada kinerja jika meningkatkan kepuasan kerja misalnya akan lebih mudah bagi karyawan untuk melakukan pekerjaan dan merasa lebih dihargai. Jones et al. (2008) menyebutkan bahwa jika pekerja tidak puas mereka akan bereaksi dengan beberapa cara, yaitu melalui rasa loyalitas, mekanisme suara, mengabaikan tanggung jawab dengan ketidakhadiran, keterlambatan, pemukulan atau usaha yang berkurang dan atau keluar atau berhenti dari pekerjaan. Menggunakan indikator pelatihan yang digunakan oleh Jones et al. (2008); maka dibahas didalamnya apakah pekerja memperoleh kesempatan mengikuti pelatihan disela pekerjaan harian mereka dalam 12 bulan terakhir dengan menggunakan tiga ukuran, yaitu sebagai berikut:

a) Berapa proporsi anggota berpengalaman dari kelompok pekerja yang diberi kesempatan mengikuti pelatihan dari tugas sehari-hari mereka pada hari normal dalam 12 bulan terakhir;

b) Berapa banyak rata-rata hari pelatihan yang diperoleh oleh pekerja selama 12 bulan terakhir; dan

c) Menghitung proporsi pekerja yang mengatakan memperoleh pelatihan pada tahun sebelumnya.

\subsection{Kepuasan Kerja}

Kepuasan kerja adalah kumpulan perasaan karyawan tentang apa yang dirasakan atas pekerjaannya, apakah senang atau tidak senang dan sebagai bentuk interaksi karyawan dengan lingkungan pekerjaannya atau sebagai hasil persepsi sikap mental, serta menjadi bentukl penilaian karyawan terhadap pekerjaan yang dijalani. Perasaan karyawan dalam bekerja tercermin dari sikap dan perilakunya dalam bekerja (2014, p.291). Darsono \& Siswandoko (2011, p.214), menafsirkan kepuasan kerja akan timbul jika ada kesesuaian antara harapan dengan kenyataan yang ada, atau ada kesesuaian antara imbalan atau upah yang diterima sesuai yang diharapkan oleh pegawai. Atau dapat dikatakan kepuasan kerja merupakan perasaan karyawan yang timbul baik itu menyenangkan atau yang tidak menyenangkan berdasarkan imbalan material dan imbalan psikologis (non material).

Kreitner \& Kinicki (2007) menjelaskan bahwa terdapat lima dampak dari individu yang puas terhadap pekerjannya:

a) Kepuasan kerja karyawan memiliki hubungan yang negatif dan lemah terhadap upaya mengurangi tingkat ketidakhadiran (absenteeism) karyawan;

b) Kepuasan kerja karyawan memiliki hubungan yang positif dan kuat serta mampu menghindari karyawan dari keinginan dan pemikiran seorang karyawan untuk keluar dari pekerjannya;

c) Kepuasan kerja karyawan memiliki hubungan yang moderat dan negatif terhadap tingkat turnover karyawan;

d) Stress kerja berhubungan dengan turnover, dan juga tingkat ketidakhadiran. Dengan meningkatkan kepuasan kerja karyawan diharapkan perusahaan akan mampu menggurangi stres kerja yang dihadapi karyawan;

e) Kinerja (job performance) kepuasan kerja dan kinerja karyawan memiliki hubungan yang positif moderat (hubungannya tidak terlalu kuat namunt juga tidak terlalu lemah) baik secara tidak langsung maupun langsung terhadap kinerja karyawan.

Rivai (2005, p.16), kepuasan kerja adalah perasaan yang dirasaan oleh individu terhadap pekerjaannya. 
Perasaan itu bisa merupakan suatu penilaian mengenai seberapa jauh pekerjaannya secara keseluruhan mampu memuaskan kebutuhannya. Menggunakan Indikator Kepuasan Kerja yang digunakan oleh Jones et al. (2008) menggunakan enam ukuran langsung kepuasan kerja dimana pekerja diberikan pertanyaan seberapa puas mereka dengan ukuran sebagai berikut:

a) Rasa prestasi yang mereka dapatkan dari pekerjaan (achievement);

b) Ruang lingkup untuk menggunakan inisiatif sendiri (initative);

c) Pengaruh atas pekerjaan (influence);

d) Pelatihan yang mereka terima (training);

e) Jumlah pembayaran yang mereka terima (pay); dan

f) Pekerjaan itu sendiri (work itself).

\subsection{Kinerja Tempat Kerja}

Menurut (Guritno \& Waridin, 2005) kinerja adalah perbandingan hasil kerja yang dicapai oleh karyawan dengan acuan yang telah ditetapkan. Hakim (2006) menjelaskan kinerja adalah suatu hasil kerja yang dicapai oleh suatu individu yang kemudian disesuaikan dengan tugas atau peranaan individu tersebut dalam suatu perusahaan atau organisasi dalam suatu periode waktu tertentu, kemudian dihubungkan dengan ukuran nilai atau standar tertentu dari perusahaan atau organisasi yang menjadi tempat dimana individu tersebut bekerja.

Kinerja tempat kerja atau kinerja organisasi, Menurut Wibowo dalam Pasolong (2010, p.176), kinerja organisasi adalah efektifitas organisasi yang secara keseluruhan untuk kebutuhan yang ditetapkan pada setiap kelompok yang berkenaan melalui cara-cara yang sistematik dan untuk meningkatkan kemampuan organisasi untuk mencapai kebutuhannya secara lebih efektif. Pasolong (2010, p.375) mengatakan, kinerja pegawai dan kinerja organisasi memiliki hubungan yang erat. Agar tujuan dalam suatu organisasi, sumber daya yang ada dalam organisasi itu harus dijalankan oleh pegawai sebagai pelaku utama dalam mencapai tujuan organisasi. Pada dasarnya kinerja organisasi merupakan tanggung jawab setiap individu yang bekerja dan ada dalam organisasi. Apabila dalam organisasi setiap individu bekerja dengan baik, berprestasi, bersemangat dan memberikan kontribusi terbaik mereka terhadap organisasi maka kinerja organisasi secara keseluruhan akan baik. Dengan demikian, kinerja organisasi merupakan cermin dari kinerja individu

Menggunakan indikator kinerja tempat kerja yang digunakan oleh Jones et al. (2008), maka dapat dipaparkan yaitu sebagai berikut:

a) Selama 12 bulan terakhir berapa persen hari kerja yang hilang karena karyawan sakit atau absen dari perusahaan; b) Secara total berapa banyak karyawan yang ada di daftar gaji di perusahaan yang berhenti bekerja karena mengundurkan diri secara sukarela; dan

c) Penilaian responden (karyawan) terhadap keuangan tempat kerja mereka, produktivitas tenaga kerja dan kualitas produk.

\section{Metode Penelitian}

Penelitian ini menggunakan metode explanatory research dengan pendekatan kuantitatif. Konsep dalam penelitian ini ada tiga yaitu, pelatihan, kepuasan kerja dan kinerja tempat kerja dengan variabel bebas pelatihan (X), variabel terikat Kinerja Tempat Kerja (Y) dan variabel interverning kepuasan kerja (Z). Teknik pengumpulan data melalui, penyebaran kuesioner, wawancara dan dokumentasi. Data kuisioner sebagai data primer dan wawancara serta dokumentasi sebagai data sekunder.

Populasi dalam penelitian ini adalah keseluruhan karyawan di Satpol PP dan Damkar Kabupaten Semarang yang berjumlah 160 orang. Penelitian ini tidak menggunakan teknik pengambilan sampel, menggunakans eluruh populasi sebagai responden dari penelitian. Sampel yang digunakan sebanyak 126 orang.

Ada pun penelitian ini menggunakan variabel dummy pada variabel $(\mathrm{X})$ dengan menggunakan coding data, varibel $(\mathrm{Z})$ dan variabel $(\mathrm{Y})$ menggunakan skala likert dalam menjawab pertanyaan yang pada kuisioner penelitian. Skala likert adalah alat ukur yang digunakan dalam penelitian untuk menjadikan data interval (Cooper $\&$ Schindler, 2008). Skala likert yang digunakan adalah skala lima dengan kategori, yaitu:

- Skor 1 untuk menggambakan jawaban sangat tidak setuju;

- Skor 2 untuk menggambarkan jawaban tidak setuju;

- Skor 3 untuk menggambarkan jawaban netral;

- Skor 4 untuk mengambarkan jawaban setuju; dan

- Skor 5 untuk menggambarkan jawaban sangat setuju.

Untuk uji asumsi klasik, dilakukan tiga jenis pengujian, yaitu uji normalitas, uji heteroskedatisitas, dan uji multikolonieritas. Uji normalitas memiliki tujuan untuk menguji apakah dalam model regresi, variabel dependen, dan variabel independen mempunyai distribusi yang normal atau tidak. Uji Heteroskedatisitas memiliki tujuan untuk mengetahui ada atau tidaknya kesamaan varian dari residual pada model regresi. Multikoliniertas berarti adanya hubungan linier, di antara beberapa atau semua variabel yang menjelaskan dari model regresi. Prasyarat yang harus terpenuhi dalam model regresi adalah adalah memiliki distribusi data normal, tidak memiliki heteroskedatisitas, dan tidak memiliki multikolineritas.

Untuk metode analisis data, digunakan uji validitas dan reliabilitas. Uji validitas bertujuan untuk mengukur 
kebenaran suatu kuisioner. Uji reliabilitas bertujuan untuk mengukur suatu kuisioner dengan menggunakan indikator dari variabel. Suatu model kuisioner dikatakan sahih jika jawaban seorang sampel terhadap pertanyaan bersifat konsisten atau stabil dari waktu ke waktu (Sugiyono, 2010).

Analisis regresi pada penelitian ini digunakan untuk menguji apakah pelatihan (X) dan kepuasan kerja (Z) memiliki hubungan terhadap kinerja tempat kerja (Y) pada pegawai Satpol PP dan Damkar Kabupaten Semarang. Langkah yang dilakukan untuk melihat berapa besar hubungan variabel independen terhadap variabel dependen, sehingga perlu untuk mengetahui nilai R2 (koefisien determinasi). Priyatno (2010) mengatakan analisis determinasi digunakan untuk mengetahui persentase hubungan variabel independen $(\mathrm{X} 1, \mathrm{Z})$ secara serentak terhadap variabel dependen (Y). Prosedur yang digunakan untuk menguji hipotesis adalah prosedur uji $F$ dan uji t. Uji $\mathrm{F}$ digunakan untuk menunjukkan apakah semua variabel bebas yang digunakan dalam model mempunyai pengaruh secara simultan terhadap variabel terikat. Uji t digunakan untuk menunjukkan seberapa jauh pengaruh satu variabel penjelas secara parsial dalam menjelaskan variabel-variabel terikat (Kuncoro, 2007). Selain itu juga digunakan path analisis atau analisis jalur untuk mengetahui peran variabel interverning dalam penelitian ini. Analisis Jalur adalah suatu teknik yang digunakan menganalisis hubungan sebab akibat yang muncul pada persamaan regresi berganda jika variabel bebasnya mempengaruhi variabel tergantung tidak hanya secara lagsung tetapi juga secara tidak langsung (Sarwono, 2007).

\section{Hasil Penelitian dan Pembahasan}

\subsection{Uji Validitas}

Sugiyono (2008, p.137) mengatakan bahwa instrument pengumpulan data akan dapat dikatakan valid apabila mampu dan dapat mengungkapkan informasi dan data dari variabel yang diteliti secara tepat apa yang diinginkan atas hasil dari penelitian tersebut. Uji validitas dalam penelitian ini dimaksudkan untuk melihat konsistensi variabel bebas dengan apa yang akan diukur. Pengujian validitas ini mengkorelasikan masing-masing skor item dengan skor total atau dikenal dengan korelasi Bivariate Pearson.

Tabel 1 Hasil Uji Validitas

\begin{tabular}{|c|l|c|c|c|}
\hline No & \multicolumn{1}{|c|}{ Variabel } & $\begin{array}{c}\mathrm{R} \\
\text { hitung }\end{array}$ & $\begin{array}{c}\mathrm{R} \\
\text { tabel }\end{array}$ & Keterangan \\
\hline 1 & $\begin{array}{l}\text { Pelatihan (X) } \\
\text { Item 1 }\end{array}$ & 40.53 & 1.66 & Valid \\
\hline 2 & Kepuasan Kerja & & & \\
& (Z) & 12.30 & 1.66 & Valid \\
& Item 1 & 9.09 & 1.66 & Valid \\
& Item 2 & 13.19 & 1.66 & Valid \\
& Item 3 & & \\
\hline
\end{tabular}

\begin{tabular}{|c|l|c|c|c|}
\hline No & \multicolumn{1}{|c|}{ Variabel } & $\begin{array}{c}\mathrm{R} \\
\text { hitung }\end{array}$ & $\begin{array}{c}\mathrm{R} \\
\text { tabel }\end{array}$ & Keterangan \\
\hline \multirow{3}{*}{} & Item 4 & 11.21 & 1.66 & Valid \\
& Item 5 & 8.20 & 1.66 & Valid \\
& Item 6 & 7.43 & 1.66 & Valid \\
& Item 7 & 9.17 & 1.66 & Valid \\
\hline 3 & Kinerja Tempat & & & \\
& Kerja (Y) & & & \\
& Item 1 & 17.67 & 1.66 & Valid \\
& Item 2 & 22.08 & 1.66 & Valid \\
& Item 3 & 12.23 & 1.66 & Valid \\
\hline
\end{tabular}

Sumber: Hasil analisis, 2019

\subsection{Uji Reliabilitas}

Menurut Sekaran (2006) untuk mengukur konsisten tidaknya jawaban seseorang terhadap item-item pernyataan di dalam sebuah kuesioner digunakan uji reliabilitas. Hasil pengujian realibilitas terhadap seluruh item/ pertanyaan yang digunakan dalam penelitian ini akan menggunakan formula cronbach alpha (koefisien alpha cronbach), yang secara umum yang akan dianggap nilainya reliabel apabila nilai alpha cronbachnya $>0,6$ (Ghozali, 2011).

Tabel 2 Hasil Uji Reliabilitas

\begin{tabular}{|l|l|l|}
\hline Variabel Penelitian & \multicolumn{1}{|c|}{$\begin{array}{c}\text { Alpha } \\
\text { Cronbach's }\end{array}$} & Keterangan \\
\hline Pelatihan (X) & 0.694 & Reliabel \\
\hline Kepuasan Kerja (Z) & 0.789 & Reliabel \\
\hline $\begin{array}{l}\text { Kinerja Tempat } \\
\text { Kerja (Y) }\end{array}$ & 0.769 & Reliabel \\
\hline
\end{tabular}

Sumber: Hasil analisis, 2019

\subsection{Uji Asumsi Klasik}

Uji asumsi klasik dapat digunakan untuk mendeteksi ada atau tidaknya penyimpangan asumsi klasik atau persamaan regresi berganda yang digunakan. Pengujian ini terdiri dari uji normalitas, uji multikolinieritas, dan uji heteroskedastisitas.

\subsubsection{Uji Normalitas}

Uji normalitas ini digunakan untuk menguji apakah model regresi variabel residual atau variabel pengganggu memiliki distribusi normal. Terdapat dua cara yang bisa digunakan untuk mendeteksi apakah residual berdistribusi normal atau tidak yaitu dengan analisis grafik dan uji statistik. Distribusi normal akan membentuk satu garis lurus diagonal (Ghozali, 2013). Data berdistribusi normal jika nilai signifikansi diatas 0,05 atau Zhitung dibawah Ztabel.

Tabel 3 Hasil Uji Normalitas

\begin{tabular}{|l|c|c|c|}
\hline Variabel & Pelatihan & $\begin{array}{c}\text { Kepuasan } \\
\text { Kerja }\end{array}$ & $\begin{array}{c}\text { Kinerja } \\
\text { Tempat Kerja }\end{array}$ \\
\hline $\mathrm{N}$ & 126 & 126 & 126 \\
$\mathrm{Z}$ hitung & 1.00 & 0.11 & 0.16 \\
\hline
\end{tabular}

Sumber: Hasil analisis, 2019 
Berdasarkan hasil uji normalitas yang diperoleh dari masing - masing residual pada setiap model regresi memiliki nilai signifikansi diatas 0,05 , sehingga dapat dikatakan bahwa residual berdistribusi normal.

\subsubsection{Uji Heteroskedastisitas}

Uji heteroskedastisitas digunakan untuk melihat atau menguji apakah dalam model regresi terjadi ketidaksamaan variance dari residual satu pengamatan kepengamatan yang lain. Apabila sebuah variance dari residual satu pengamatan ke pengamatan yang lain bernilai tetap, maka dapat dikatakan memiliki homoskedastisitas dan jika memiliki nilai yang berbeda disebut heteroskesdatisidas. Model regresi yang dapat dikatakan baik adalah yang memiliki nilai homoskedastisitas atau tidak terjadi heteroskesdatisidas. Kebanyakan data crossection mengandung situasi heteroskesdatisidas karena data crossection ini menghimpun data yang dikatakan mewakili berbagai ukuran dari mulai besar, sedang, dan kecil (Ghozali, 2013, p.139).

Tabel 4 Hasil Uji heteroskedastisitas

\begin{tabular}{|c|c|c|c|c|c|c|}
\hline & & & oefficien & & & \\
\hline & & $\begin{array}{r}\text { Unstan } \\
\text { Coef }\end{array}$ & $\begin{array}{l}\text { rdized } \\
\text { ients }\end{array}$ & $\begin{array}{c}\text { Standardized } \\
\text { Coefficients }\end{array}$ & & \\
\hline Mode & & B & $\begin{array}{l}\text { Std. } \\
\text { Error }\end{array}$ & Beta & $\mathrm{t}$ & Sig. \\
\hline 1 & (Constant) & .003 & .099 & & .027 & .979 \\
\hline & Pelatihan (X) & .038 & .025 & .137 & 1.517 & .132 \\
\hline & $\begin{array}{l}\text { Kepuasan } \\
\text { Kerja (Z) }\end{array}$ & .029 & .070 & .038 & .419 & .676 \\
\hline
\end{tabular}

Sumber: Hasil analisis, 2019

Berdasarkan Tabel 4 diatas korelasi antara variabel independen dengan residual di dapat signifikansi 0.132 dan 0.676 yang berarti lebih dari 0.05 , sehingga dapat dikatakan bahwa tidak terjadi masalah heteroskedastisitas pada model regresi.

\subsubsection{Uji Multikolinieritas}

Uji multikoliniearitas bertujuan untuk menguji apakah model regresi ditemukan adanya korelasi antar variabel bebas (independen). Model regresi yang baik seharusnya tidak terjadi korelasi diantara variabel independen. Variabel yang menyebabkan multikoloniearitas dapat dilihat dari nilai tolerance yang lebih besar dari 0,1 (>0,1) dan VIF yang kurang dari 10 (Ghozali, 2013, p.105).

Tabel 5 Hasil Uji Multikolinieritas

\begin{tabular}{|c|c|c|c|}
\hline \multicolumn{4}{|c|}{ Coefficients $^{\mathrm{a}}$} \\
\hline & & Collinearity & Statistics \\
\hline \multicolumn{2}{|l|}{ Model } & Tolerance & VIF \\
\hline \multirow[t]{3}{*}{1} & (Constant) & & \\
\hline & Pelatihan & .975 & 1.026 \\
\hline & Kepuasan Kerja & .975 & 1.026 \\
\hline
\end{tabular}

a. Dependent Variable: Kinerja Tempat Kerja

Sumber: Hasil analisis, 2019

\subsection{Koefisien Jalur}

\subsubsection{Koefisien Jalur Pelatihan (X) terhadap Kinerja}

Tabel 6 Hasil Uji t jalur Pelatihan (X)

terhadap Kinerja Tempat Kerja (Y)

\begin{tabular}{|c|c|c|c|c|c|c|}
\hline \multirow[b]{2}{*}{ Model } & & \multicolumn{2}{|c|}{$\begin{array}{l}\text { Unstandardized } \\
\text { Coefficients }\end{array}$} & \multirow{2}{*}{$\begin{array}{c}\text { Standardized } \\
\text { Coefficients } \\
\text { Beta }\end{array}$} & \multirow[b]{2}{*}{$\mathrm{t}$} & \multirow[b]{2}{*}{ Sig. } \\
\hline & & $\mathrm{B}$ & $\begin{array}{l}\text { Std. } \\
\text { Error }\end{array}$ & & & \\
\hline 1 & (Constant) & 1.417 & .007 & & 198.714 & .000 \\
\hline & Pelatihan & .054 & .032 & .153 & 1.721 & .088 \\
\hline
\end{tabular}

Sumber: Hasil analisis, 2019

Dari tabel diatas dapat diketahui bahwa nilai t hitung dari variabel pelatihan sebesar 1.721 nilai t hitung lebih kecil dari $\mathrm{t}$ tabel $=1.979$ dan signifikansi $0.88>0.05$. Hasil regresi diatas terlihat bahwa pelatihan memiliki hubungan positif dan tidak signifikan terhadap kinerja tempat kerja. Karena variabel pelatihan merupakan variabel dummy yang menggunakan nominal 0 dan 1, sehingga dilakukan persamaan, yaitu sebagai berikut:

$$
\begin{aligned}
& \mathrm{Y}=\mathrm{B} 0+\mathrm{B} 1 \\
& \mathrm{Y}=1.417+0.54 \\
& \mathrm{Y}=1.957
\end{aligned}
$$

Pada penggunaan variabel dummy ini terlihat untuk pegawai yang memperoleh pelatihan memiliki nilai hubungan kepada kinerja tempat kerja sebesar 0.54 lebih besar daripada pegawai yang tidak memperoleh kesempatan mengikuti pelatihan. Karena kita melihat hubungan pelatihan terhadap kinerja tempat kerja, sehingga ditarik kesimpulan bahwa pelatihan memperngaruhi kinerja tempat kerja sebesar 1.957. Dengan kata lain jika pelatihan naik sebesar 1\% akan meningkatkan kinerja tempat kerja sebesar $1.957 \%$. Sebaliknya jika pelatihan mengalami penurunan sebesar $1 \%$ maka kinerja tempat kerja juga akan mengalami penurunan sebesar $1.957 \%$.

Konstanta kinerja tempat kerja sebesar 1.417 memiliki arti jika variabel independen memiliki nilai atau mengalami perubahan konstanta sebesar $1 \%$ maka nilai kinerja tempat kerja atau variabel dependen akan naik sebesar $1.417 \%$ dan sebaliknya, jika nilai konstanta turun $1 \%$ maka nilai kinerja tempat kerja akan turun sebesar $1.417 \%$.

Tabel 7 Koefisien Determinasi Hubungan Pelatihan (X) terhadap Kinerja Tempat Kerja

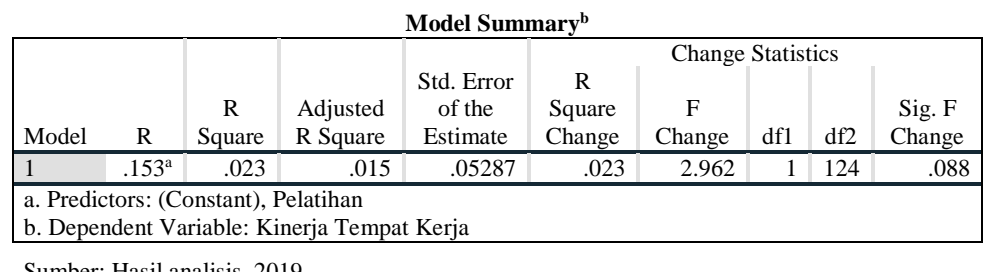


Dari tabel 7 diketahui bahwa nilai Adjusted $\mathrm{R}$ Square sebesar 0,015 artinya bahwa variabel independen mampu menjelaskan $1,5 \%$ variasi yang terjadi dalam variabel dependen, sedangkan 98.5,2\% dijelaskan oleh variabel lain yang tidak dianalisis dalam model penelitian ini. Pengujian hipotesis menunjukkan besarnya angka signifikansi sebesar $0.88>0.05$ sehingga $\mathrm{H} 0$ diterima dan H1 ditolak.

Berdasarkan perhitungan diatas dapat disimpulkan bahwa hipotesis pertama berbunyi - Diduga terdapat hubungan signifikan dari variabel pelatihan terhadap kinerja tempat kerja - tidak terbukti.

\subsubsection{Koefisien Jalur Pelatihan (X) terhadap Kepuasan $\operatorname{Kerja}(Z)$}

Tabel 8 Hasil Uji t Jalur Pelatihan (X) terhadap Kepuasan Kerja (Z)

\begin{tabular}{|c|c|c|c|c|c|c|}
\hline \multicolumn{7}{|c|}{ Coefficients $^{\mathrm{a}}$} \\
\hline \multirow{2}{*}{\multicolumn{2}{|c|}{ Model }} & \multicolumn{2}{|c|}{$\begin{array}{l}\text { Unstandardized } \\
\text { Coefficients }\end{array}$} & \multirow{2}{*}{$\begin{array}{l}\text { Standardize } \\
d \\
\text { Coefficients } \\
\text { Beta }\end{array}$} & \multirow[b]{2}{*}{$\mathrm{T}$} & \multirow[b]{2}{*}{ Sig. } \\
\hline & & B & Std. Error & & & \\
\hline \multirow[t]{2}{*}{1} & (Constant) & 25.222 & .962 & & $\begin{array}{r}26.21 \\
2\end{array}$ & .000 \\
\hline & Pelatihan & 1.051 & .587 & .159 & 1.792 & .076 \\
\hline
\end{tabular}

Sumber: Hasil analisis, 2019

Dari Tabel 8 diatas dapat diketahui bahwa nilai $\mathrm{t}$ hitung dari variabel pelatihan sebesar 1.792 nilai t hitung lebih besar dari t tabel $=1,979$ dan signifikansi $0.076>$ 0.05 . Hasil regresi diatas terlihat bahwa pelatihan tidak memiliki hubungan positif dan tidak signifikan terhadap kepuasan kerja. Karena variabel pelatihan merupakan variabel dummy yang menggunakan nominal 0 dan 1 , sehingga dilakukan persamaan:

$$
\begin{aligned}
& Z=B 0+B 1 \\
& Z=25.222+1.051 \\
& Z=26.271
\end{aligned}
$$

Pada penggunaan variabel dummy ini terlihat untuk pegawai yang memperoleh pelatihan memiliki nilai hubungan kepada kinerja tempat kerja sebesar 1.051 lebih besar daripada pegawai yang tidak memperoleh kesempatan mengikuti pelatihan. Karena kita melihat hubungan pelatihan terhadap kepuasan kerja, sehingga ditarik kesimpulan bahwa pelatihan memperngaruhi kepuasan kerja sebesar 26.271. Dengan kata lain jika pelatihan naik sebesar $1 \%$ akan meningkatkan kepuasan kerja sebesar $26.271 \%$. Sebaliknya jika pelatihan mengalami penurunan sebesar $1 \%$, maka kepuasan kerja juga akan mengalami penurunan sebesar $26.271 \%$.

Konstanta kepuasan kerja sebesar 25.222 memiliki arti jika variabel independen bernilai konstanta atau mengalami perubahan sebesar $1 \%$ maka nilai kepuasan kerja atau variabel dependen akan naik sebesar 25.222\% dan sebaliknya, jika turun $1 \%$ maka nilai kinerja tempat kerja akan turun sebesar $25.222 \%$.

Tabel 9 Koefisien Determinasi Jalur Pelatihan (X) terhadap Kinerja Tempat Kerja

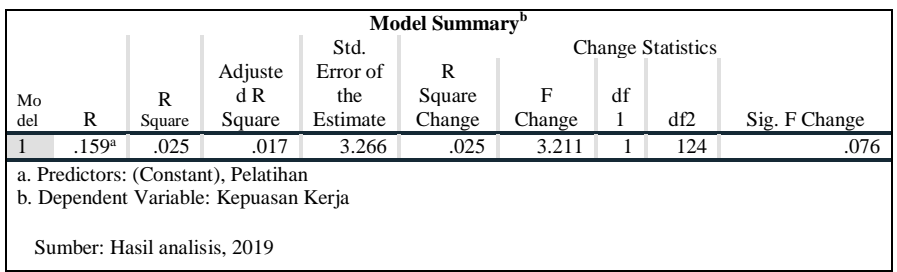

Berdasarkan tabel 9 diatas, dapat diketahui bahwa nilai Adjusted R Square sebesar 0,017. Artinya bahwa variabel independen mampu menjelaskan $1,7 \%$ variasi yang terjadi dalam variabel dependen, sedangkan $98.3 \%$ dijelaskan oleh variabel lain yang tidak dianalisis dalam model penelitian ini.

Pengujian hipotesis menunjukkan besarnya angka signifikansi sebesar $0.76>0.05$ sehingga $\mathrm{H} 0$ diterima dan $\mathrm{H} 2$ ditolak. Berdasarkan perhitungan diatas dapat disimpulkan bahwa hipotesis kedua berbunyi - Diduga terdapat hubungan pengaruh signifikan dari variabel pelatihan terhadap kepuasan kerja tidak terbukti.

\subsubsection{Koefisien Jalur Kepuasan Kerja (Z) terhadap Kinerja Tempat Kerja $(Y)$}

\begin{tabular}{|c|c|c|c|c|c|}
\hline \multicolumn{6}{|c|}{ Coefficientsa } \\
\hline \multirow[b]{2}{*}{ Model } & \multicolumn{2}{|c|}{$\begin{array}{l}\text { Unstandardized } \\
\text { Coefficients }\end{array}$} & \multirow{2}{*}{$\begin{array}{l}\text { Standardized } \\
\text { Coefficients } \\
\text { Beta }\end{array}$} & \multirow[b]{2}{*}{$\mathrm{t}$} & \multirow[b]{2}{*}{ Sig. } \\
\hline & $\mathrm{B}$ & Std. Error & & & \\
\hline 1 (Constant) & 1.518 & 1.134 & & 1.339 & .183 \\
\hline Kepuasan Kerja & .342 & .042 & .591 & 8.161 & .000 \\
\hline
\end{tabular}

Tabel 10 Hasil Uji t Jalur Kepuasan Kerja (Z) terhadap Kinerja Tempat Kerja (Y)

Sumber: Hasil analisis, 2019

Berdasarkan tabel 10 diatas dapat diketahui bahwa nilai t hitung dari variabel kepuasan kerja sebesar 8.161 nilai $\mathrm{t}$ hitung lebih besar dari $\mathrm{t}$ tabel $=1,979$ dan signifikansi $0.00<0.05$. Hasil regresi diatas terlihat bahwa Kepuasan Kerja memiliki hubungan positif dan signifikan terhadap Kinerja Tempat Kerja. Konstanta kinerja tempat kerja sebesar 1.518 memiliki arti jika variabel independen bernilai konstanta atau mengalami perubahan sebesar $1 \%$ maka nilai kinerja tempat kerja atau variabel dependen akan naik sebesar $1.518 \%$ dan sebaliknya, jika turun $1 \%$ maka nilai kinerja tempat kerja atau variabel dependen akan menurun sebesar $0.368 \%$.

Koefisien regresi kepuasan kerja 0.342 menunjukan hubungan kepuasan kerja terhadap kinerja tempat kerja. Dengan kata lain, jika kepuasan kerja naik 1\%, maka kinerja tempat kerja akan meningkat sebesar $0.342 \%$. Kemudian sebaliknya jika kepuasan kerja turun $1 \%$, maka kinerja tempat kerja akan menurun sebesar $0.342 \%$. 
Tabel 11 Koefisien Determinasi Jalur Kepuasan Kerja (Z) terhadap Kinerja Tempat Kerja (Y)

\begin{tabular}{|c|c|c|c|c|c|c|c|c|c|}
\hline \multicolumn{10}{|c|}{ Model Summary ${ }^{\mathrm{b}}$} \\
\hline & & & & & & Change & Statis & ics & \\
\hline Model & $\mathrm{R}$ & $\begin{array}{c}\mathrm{R} \\
\text { Squar } \\
\mathrm{e}\end{array}$ & $\begin{array}{l}\text { Adjusted } \\
\text { R Square }\end{array}$ & $\begin{array}{l}\text { of the } \\
\text { Estimat } \\
\text { e }\end{array}$ & $\begin{array}{c}\mathrm{R} \\
\text { Square } \\
\text { Change }\end{array}$ & $\begin{array}{c}\mathrm{F} \\
\text { Change }\end{array}$ & df1 & df2 & $\begin{array}{c}\text { Sig. F } \\
\text { Chang } \\
\text { e }\end{array}$ \\
\hline 1 & $\begin{array}{r}.591 \\
\mathrm{a}\end{array}$ & .349 & .344 & 1.544 & .349 & 66.607 & 1 & $\begin{array}{r}12 \\
4\end{array}$ & .000 \\
\hline \multicolumn{10}{|c|}{ a. Predictors: (Constant), Kepuasan Kerja } \\
\hline
\end{tabular}

Dari tabel 11 diketahui bahwa nilai Adjusted $\mathrm{R}$ Square sebesar 0,344 artinya bahwa variabel independen mampu menjelaskan $34,4 \%$ variasi yang terjadi dalam variabel dependen. Sedangkan $98.3 \%$ dijelaskan oleh variabel lain yang tidak dianalisis dalam model penelitian ini.

Pengujian hipotesis menunjukkan besarnya angka signifikansi sebesar $0.00>0.05$, sehingga $\mathrm{H} 0$ ditolak dan H3 diterima dapat disimpulkan bahwa hipotesis ketiga berbunyi - Diduga terdapat hubungan signifikan dari variabel kepuasan kerja terhadap kinerja tempat kerja, terbukti.

\subsubsection{Koefisien Jalur Pelatihan $(X)$ terhadap Kinerja Tempat Kerja (Y) melalui Kepuasan Kerja}

Tabel 12 Koefisien Determinasi Jalur Pelatihan (X) terhadap Kinerja Tempat Kerja (Y)

\begin{tabular}{|c|c|c|c|c|c|c|}
\hline \multirow[b]{2}{*}{ Model } & & \multicolumn{2}{|c|}{$\begin{array}{l}\text { Unstandardized } \\
\text { Coefficients }\end{array}$} & \multirow{2}{*}{$\begin{array}{l}\text { Standardized } \\
\text { Coefficients } \\
\text { Beta }\end{array}$} & \multirow[b]{2}{*}{$\mathrm{t}$} & \multirow[b]{2}{*}{ Sig. } \\
\hline & & B & Std. Error & & & \\
\hline 1 & (Constant) & 1.542 & 1.134 & & 1.359 & .177 \\
\hline & Kepuasan Kerja & .335 & .042 & .579 & 7.896 & .000 \\
\hline & Pelatihan & .288 & .281 & .075 & 1.026 & .307 \\
\hline
\end{tabular}

a. Dependent Variable: Kinerja Tempat Kerja

Sumber: Hasil analisis, 2019

$$
\begin{aligned}
\mathrm{Y} & =1.542+0.335+0.288 \\
& =2.165
\end{aligned}
$$

Tabel 13 Tabel R Jalur Pelatihan (X) terhadap Kinerja

\begin{tabular}{|c|c|c|c|c|}
\hline \multicolumn{5}{|c|}{ Model Summary } \\
\hline Model & $\mathrm{R}$ & R Square & $\begin{array}{c}\text { Adjusted R } \\
\text { Square } \\
\end{array}$ & $\begin{array}{c}\text { Std. Error of the } \\
\text { Estimate }\end{array}$ \\
\hline 1 & $.596^{\mathrm{a}}$ & .355 & .344 & 1.543 \\
\hline
\end{tabular}
Tempat Kerja (Y) Melalui Kepuasan Kerja (Y)

Sumber: Hasil analisis, 2019

Konstanta kinerja tempat kerja sebesar 1.542 memiliki arti jika variabel independen mengalami perubahan atau bernilai konstanta sebesar 1\%, maka nilai dari kinerja tempat kerja atau variabel dependen akan naik sebesar $1.542 \%$. Sebaliknya, jika mengalami penurunan $1 \%$, maka nilai dari kinerja tempat kerja akan menurun sebesar $1.542 \%$ Koefisien regresi kepuasan kerja sebesar 0.335 menunjukan besarnya hubungan kepuasan kerja terhadap kinerja tempat kerja. Dapat dikatakan jika kepuasan kerja naik $1 \%$ maka kinerja tempat kerja akan naik sebesar $0.335 \%$ dan sebaliknya jika kepuasan kerja menurun $1 \%$ maka kinerja tempat kerja akan mengalami penurunan sebesar $0.335 \%$. Koefisien regresi pelatihan sebesar 0.288 menunjukan besarnya hubungan pelatihan terhadap kinerja tempat kerja. Dapat dikatakan jika pelatihan naik $1 \%$ maka kinerja tempat kerja akan naik sebesar $0.335 \%$ dan sebaliknya jika pelatihan menurun $1 \%$ maka kinerja tempat kerja akan mengalami penurunan sebesar $0.335 \%$.

\subsection{Path Analysis (Analisis Jalur)}

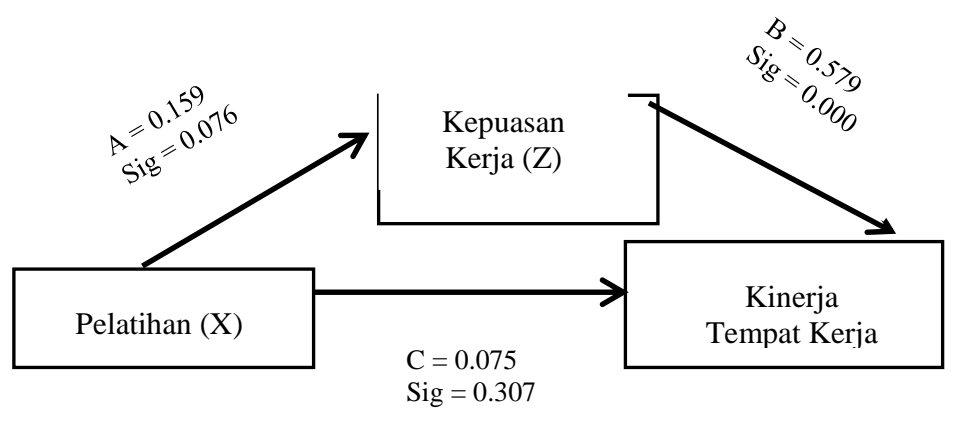

Gambar 1 Hasil Analisis Jalur untuk Path Analysis Sumber: Hasil analisis, 2019

Tabel 13 Uji $\mathrm{R}^{2}$ untuk Path Analysis

\begin{tabular}{|l|c|c|}
\hline \multicolumn{1}{|c|}{ Keterangan } & $\mathrm{R}^{2}$ & Adjusted $\mathrm{R}^{2}$ \\
\hline Persamaan II & 0.025 & 0.017 \\
\hline Persamaan IV & 0.355 & 0.344 \\
\hline
\end{tabular}

Sumber: Hasil analisis, 2019

- e1 pada struktur persamaan II dengan cara : $(1-\mathrm{R} 2) 2=(1-$ $0.025) 2=0.95$

- e2 pada struktur persamaan IV dengan cara : $(1-\mathrm{R} 2) 2=(1-$ $0.355) 2=0.42$

- $\quad$ Total $\mathrm{R} 2=1-(\mathrm{e} 1 \times \mathrm{e} 2)=1-(0.95 \times 0.42)=1-0.399=$ 0.601

Kesimpulan hasil total R2 pada model path analysis yang digunakan adalah 0.601 atau $60.1 \%$ artinya bahwa model dengan persamaan ini, variabel independen (pelatihan dan kepuasan kerja) dapat menjelaskan variabel dependen (kinerja tempat kerja) sebesar 60.1\% sisanya sebesar $39.9 \%$ dijelaskan oleh variabel lain.

a) Hubungan Langsung

- Hubungan pelatihan terhadap kinerja tempat kerja memiliki nilai standardized coefficients beta sebesar 0.075 dengan nilai signifikansi 0.307 . Artinya bahwa pelatihan mempunyai hubungan langsung yang positif dan tidak signifikan terhadap kinerja tempat kerja;

- Hubungan pelatihan terhadap kepuasan kerja memiliki nilai standardized coefficient beta sebesar 0.159 dengan nilai signifikansi 0.076 . Artinya bahwa pelatihan mempunyai hubungan 
yang positif dan tidak signifikan terhadap kepuasan kerja; dan

- Hubungan kepuasan kerja terhadap kinerja tempat kerja memiliki nilai standardized coefficient beta sebesar 0.579 dengan signifikansi 0.000 . Artinya bahwa pelatihan mempunyai hubungan langsung yang positif dan signifikan terhadap kinerja tempat kerja.

b) Hubungan Tidak Langsung

Hubungan tidak langsung variabel pelatihan terhadap kinerja tempat kerja melalui kepuasan kerja menunjukkan bahwa hubungan pelatihan terhadap kepuasan kerja sebesar 0.159 sedangkan hubungan kepuasan kerja terhadap kinerja tempat kerja sebesar 0.579 . Hasil ini jika dikalikan (0.159 x 0.579) sama dengan 0.092. Dari perkalian koefisien tersebut daapt disimpulkan bahwa variabel kepuasan kerja dapat dijadikan variabel intervening karena nilai koefisiennya lebih besar dari hubungan langsung $(0.092>0.075)$.

c) Hubungan Total

Hubungan total variabel pelatihan terhadap kinerja tempat kerja melalui kepuasan kerja menunjukkan bahwa hubungan pelatihan terhadap kinerja tempat kerja sebesar 0.075. Sedangkan hubungan tidak langsung pelatihan terhadap kinerja tempat kerja sebesar 0.092, sehingga dapat disimpulkan bahwa hubungan total pelatihan terhadap kinerja tempat kerja sebesar 0.167 .

\subsection{Pembahasan}

\subsubsection{Pelatihan $(X)$ Terhadap Kinerja Tempat Kerja $(Y)$}

Berdasarkan hasil pengujian hipotesis pertama ditemukan bahwa pelatihan tidak memiliki hubungan signifikan terhadap kinerja tempat kerja. Dapat dijelaskan dalam penelitian bahwa pelatihan belum menjadi variabel yang mempengaruhi kinerja tempat kerja dan terdapat variabel lain yang dapat mempengaruhi atau meningkatkan kinerja tempat kerja di Dinas Satpol PP dan Damkar Kabupaten Semarang berdasarkan pengamatan saat observasi misalnya kondisi pribadi pegawai, lingkungan kerja atau kurang tepatnya materi pelatihan.

Menurut Ibu Jumiati Kepala Sub Bagian Umum dan Kepegawaian salah satu hal yang menjadi penyebab karena pelatihan yang diberikan pada pegawai Dinas Satuan Polisi Pamong Praja dan Pemadam Kebakaran tidak akan berdampak sama, karena tidak semua pegawai mendapatkan pelatihan. Sehingga tidak semua pegawai juga bisa merasakan dampaknya, sehingga tidak ada hubungan signifikan yang ditunjukkan. Hasil penelitian ini selaras dengan hasil penelitian oleh Yuliati (2009) menjelaskan bahwa, tidak ada pengaruh yang signifikan antara pelatihan terhadap kinerja karena pelatihan ditujukan untuk meningkatkan prestasi kerja saat ini saja.
Penelitian yang dilakukan oleh Safitri (2013) juga menunjukkan hasil yang sama dimana dijelaskan bahwa tidak ada pengaruh yang signifikan antara pelatihan dan kinerja. Ningsi et al. (2015) juga melakukan penelitian menunjukana bahwa tidak ada pengaruh antara pelatihan dan kinerja, kemudian menjelaskan bahwa pelatihan yang semakin baik tidak menjamin kinerja akan menjadi semakin baik.

\subsubsection{Pelatihan (X) Terhadap Kepuasan Kerja (Z)}

Berdasarkan hasil pengujian hipotesis kedua ditemukan bahwa pelatihan tidak memiliki hubungan signifikan terhadap kepuasan kerja. Melihat hasil penelitian dimana variabel pelatihan tidak memiliki hubungan signifikan terhadap kepuasan karyawan, itu mungkin saja terjadi karena pelatihan yang diberikan tidak sesuai dengan kebutuhan dan keinginan pegawai, selain itu pelatihan yang diberikan tidak merata kepada semua pegawai. Dinas Satuan Polisi Pamong Praja dan Pemadam Kebakaran Kabupaten Semarang harus memperbaiki pola dan bentuk pengadaan pelatihan, sehingga menemukan pola dan bentuk pelatihan yang dapat meningkatkan kepuasan kerja pegawai. Hasil penelitian ini sesuai dan selaras dengan hasil penelitian yang dilakukan Vonny (2016) yang juga menjelaskan tentang tidak adanya pengaruh pelatihan terhadap kepuasan kerja karyawan di PT. United Tractors Cabang Manado disebaban oleh bentuk pelatihan yang diberikan oleh organisasi tidak cukup sesuai dengan kebutuhan karyawan atau bentuk pelatihan yang diberikan oleh organisasi kurang maksimal, sehingga tidak memiliki pengaruh terhadap kepuasan kerja karyawan.

\subsubsection{Kepuasan Kerja (Z) Terhadap Kinerja Tempat $\operatorname{Kerja}(Y)$}

Berdasarkan hasil pengujian hipotesis kedua ditemukan bahwa kepuasan kerja tidak memilliki hubungan signifikan terhadap kinerja tempat kerja. Kinerja karyawan adalah hasil kerja secara kualitas dan kuantitas yang dicapai oleh seseorang karyawan dalam melaksanakan tugasnya sesuai dengan tanggung jawab yang diberikan kepadanya (Mangkunegara, 2013). Karyawan dapat bekerja dengan baik bila memiliki kinerja yang cukup tinggi, sehingga dapat menghasilkan kerja yang baik. Kinerja pegawai adalah salah satu faktor penentu keberhasilan perusahaan atau organisasi dalam mencapai tujuannya. Untuk itu kinerja pegawai harus mendapat perhatian dari para pimpinan perusahaan atau organisasi, sebab menurunnya kinerja dari pegawai dapat mempengaruhi kinerja tempat kerja secara keseluruhan.

Hasil penelitian ini sesuai dan selaras dengan hasil penelitian dari Changgriawan (2017) yang mendapatkan hasil penelitian bahwa kepuasan kerja yang meningkat akan juga selaras dengan peningkatan kinerja pegawai 
yang kemudian berdampak pada kinerja tempat kerja yang juga meningkat.

\subsubsection{Pelatihan (X) Terhadap Kinerja Tempat Kerja $(Y)$ Melalui Kepuasan Kerja (Z)}

Hubungan total variabel pelatihan terhadap kinerja tempat kerja melalui kepuasan kerja menunjukkan bahwa hubungan pelatihan terhadap kinerja tempat kerja sebesar 0.075 sedangkan hubungan tidak langsung pelatihan terhadap kinerja tempat kerja sebesar 0.092. Dengan demikian dapat disimpulkan bahwa hubungan total pelatihan terhadap kinerja tempat kerja sebesar 0.167.

Hal ini menunjukan bahwa kepuasan kerja dapat menjadi variabel interverning karena pelatihan memberikan pengaruh yang lebih besar ketika melalui kepuasan kerja walaupun peningkatan yang ditunjukkan tidak terlalu berbeda jauh dengan pengaruh langsung namun sudah memenuhi syarat sebagai variabel interverning.

\section{Kesimpulan}

Berdasarkan hasil analisis statistik data penelitian baik secara deskiptif maupun secara inferensial yang telah dilakukan terhadap teori dan modal hipotesis penelitian ini, maka dapat disimpulkan sebagai berikut:

a) Pelatihan memiliki hubungan positif dan tidak signifikan terhadap kinerja tempat kerja. Hal ini terlihat dari hasil t hitung pelatihan sebesar 1.721, sehingga $t$ hitung lebih kecil dari $t$ tabel yang memiliki nilai 1.979 dengan signifikansi 0.088 dimana lebih dari 0.05 ;

b) Pelatihan memiliki hubungan positif dan tidak signifikan terhadap kepuasan kerja. Hal ini terlihat dari hasil t hitung pelatihan sebesar 1.792, sehingga $\mathrm{t}$ hitung lebih kecil dari $\mathrm{t}$ tabel yang memiliki nilai 1.979 dengan signifikansi 0.076 dimana lebih dari 0.05

c) Kepuasan kerja memiliki hubungan positif dan signifikan terhadap kinerja tempat kerja. Hal ini terlihat dari hasil bahwa nilai t hitung dari variabel pelatihan sebesar 8.161 nilai t hitung lebih besar dari t tabel $=1,979$ dan signifikansi $0.00<0.05$; dan

d) Hubungan tidak langsung variabel pelatihan terhadap kinerja tempat kerja melalui kepuasan kerja menunjukkan bahwa hubungan pelatihan terhadap kepuasan kerja sebesar 0.159. Sedangkan hubungan kepuasan kerja terhadap kinerja tempat kerja sebesar 0.579 . Hasil ini jika dikalikan $(0.159$ x 0.579$)$ sama dengan 0.092. Dari perkalian koefisien tersebut daapt disimpulkan bahwa variabel kepuasan kerja dapat dijadikan variabel intervening karena nilai koefisiennya lebih besar dari hubungan langsung $(0.092>0.075)$
Adapun saran yang dapat diberikan penulis, adalah sebagai berikut:

a) Mengingat bahwa hasil penelitian pelatihan memiliki hubungan yang positif dan walau tidak signifikan terhadap kinerja tempat kerja, ini berarti Dinas Satuan Polisi Pamong Praja dan Pemadam Kebakaran Kabupaten Semarang harus lebih memperhatikan dan memperbaiki bentuk-bentuk pelatihan yang diberikan mulai dari proses perencanaan pelatihan karena mungkin saja ada banyak faktor dimana menyebabkan tujuan dari pelatihan tidak dapat tercapai, seperti kondisi organisasi maupun kondisi internal individu;

b) Hasil penelitian pelatihan memiliki hubungan positif walau tidak signifikan terhadap kepuasan kerja. Ini berarti Dinas Satuan Polisi Pamong Praja dan Pemadam Kebakaran Kabupaten Semarang harus lebih mengkaji kembali bagaimana proses sebelum dan selama pelaksanaan pelatihan karena terlihat dari hasil penelitian pelaksanaan pelatihan yang dilakukan selama ini tidak dapat meningkatkan kepuasan kerja secara signifikan. Perlu adanya perencanaan inovasi system pelatihan yang baru agar dapat ditemukan pola yang sesuai dengan organisasi Dinas Satuan Polisi Pamong Praja dan Pemadam Kebakaran Kabupaten Semarang;

c) Kepuasan kerja memiliki hubungan positif dan signifikan terhadap kinerja tempat kerja pada Dinas Satuan Polisi Pamong Praja dan Pemadam Kebakaran Kabupaten Semarang. Hal ini dikarenakan pegawai yang merasa puas dengan sesuatu yang diberikan oleh organisasi akan memiliki kinerja yang baik yang kemudian akan ikut meningkatkan kinerja tempat kerja atau kinerja organisasi. Hasil penelitian ini bisa menjadi pedoman agar organisasi lebih mengetahui apa yang dibutuhkan oleh pegawai, memotivasi mereka, sehingga kinerja pegawai menjadi lebih baik dan bisa melaksanakan visi dan misi perusahaan tersebut, karena kunci kesuksesan perusahaan terdapat pada karyawan yang berkualitas. Langkah-langkah ini perlu menjadi prioritas dalam perencanaan tahunan Dinas Satuan Polisi Pamong Praja dan Pemadam Kebakaran Kabupaten Semarang karena kepuasan kerja pegawai merupakan hal yang sangat krusial. Pegawai dapat diberikan kepercayaan dan tanggung jawab lebih dalam suatu pekerjaan serta dapat mengambil sendiri keputusan yang perlu diambil dalam mengerjakan tugasnya. Hal ini dapat meningkatkan kepuasan kerja pegawai dalam organisasi;

d) Hasil dari penelitian ini dapat digunakan sebagai acuan menimbang untuk pengembangkan ilmu pengetahuan administrasi publik terlebih khusus pada aspek pelatihan, kepuasan kerja dan dampaknya 
terhadap kinerja tempat kerja diorganisasi sektor publik;

e) Diharapkan penelitian selanjutnya dapat menambahkan dan mengembangkan variabel lain selain dari variabel yang digunakan pada penelitian ini yang diduga mempengaruhi kinerja tempat kerja atau kinerja organisasi, seperti motivasi kerja, disiplin kerja, dan sebagainya.

\section{Daftar Pustaka}

Ahmad, S., \& Schroeder, R.G. (2003). The impact of human resource management practices on operational performance. Journal of Operational Management, 21(1), 19-43. DOI: https://doi.org/10.1016/S0272-6963(02)00056-6

Changgriawan, Garry Surya. (2017). Pengaruh Kepuasan Kerja dan Motivasi Kerja terhadap Kinerja Karyawan di One Way Production. AGORA, 5(3), 1-7.

Cooper, Donald R., \& Pamela S. Schindler. (2008). Business Research Methods. NY: McGraw-Hill.

Darsono., \& Siswandoko, Tjatjuk. (2011). Sumber Daya Manusia Abad 21. Jakarta: Nusantara Consulting.

Donni Junni Priansa. (2014). Perencanaan \& Pengembangan SDM. Bandung: Alfabeta.

Faems, D., Sels, L., DeWinne, S., \& Maes, J. (2005). The effect of individual HR domains of financial performance. International Journal of Human Resource Management, 16, 676-700. DOI: $10.1080 / 09585190500082790$

Gomes, F.C. (2000). Manajemen Sumber Daya Manusia. Yogyakarta: Andy Offset.

Gelade, G.A., \& Ivery, M. (2003). The impact of human resource management and work climate on organizational performance. Personnel Psychology, 56(2), 383-404. DOI: https://doi.org/10.1111/j.17446570.2003.tb00155. $\mathrm{x}$

Ghozali, Imam. (2011). Aplikasi Analisis Multivariate Dengan Program SPSS. Semarang: Badan Penerbit Universitas Diponegoro.

Ghozali, Imam. (2013). Aplikasi Analisis Multivariat dengan Program IBM SPSS (Edisi 7). Semarang: Penerbit Universitas Diponegoro.

Guritno, Bambang., \& Waridin. (2005). Pengaruh Persepsi Karyawan Mengenai Perilaku Kepemimpinan, Kepuasan Kerja dan Motivasi Terhadap Kinerja. JRBI, 1(1), 63-74.

Hakim, Abdul. (2006). Analisis pengaruh motivasi, komitmen organisasi dan iklim organisasi terhadap kinerja pegawai pada dinas perhubungan dan telekomunikasi provinsi jawa tengah. JRBI, 2(2), 165-180.
Jones, Melanie K., Richard J. Jones., Paul L. Latreille., \& Peter J. Sloane. (2008). Training, Job Satisfaction and Workplace Performance in Britain: Evidence from WERS 2004. Labour, Vol 23, Issue s1, 139175. Doi: https://doi.org/10.1111/j.14679914.2008.00434.x

Kreitner, Robert., \& Kinicki, Angelo. (2007). Organizational Behaviour (Seventh Edition). NY: Mc.Graw Hill International.

Kuncoro, M. (2007). Metode Kuantitatif. Yogyakarta: STIM YKPN.

Mangkunegara, Anwar Prabu. (2013). Manajemen Sumber Daya Manusia Perusahaan. Bandung: PT. Remaja Rosdakarya.

Ningsi, Citra Ayu., Taher Alhabsji., \& Hamidah Nayati Utami. (2015). Pengaruh Pelatihan dan Promosi Terhadap Motivasi dan Kinerja Karyawan (Studi pada Karyawan PT.PLN (Persero) Area Kendari). Jurnal Administrasi Publik, 5(1), 131-143.

Pasolong, Harbani. (2010). Teori administrasi publik. Bandung: Alfabeta.

Petty, M.M., Gail W. McGee., \& Jerry W. Cavender. (1984). A Meta-Analysis of the Relationship Between Individual Job Satisfaction and Individual Performance. Academy of Management Review, 9(4), 712-721.

Priyatno, D. (2010). Teknik Mudah dan Cepat Melakukan Analisis Data Penelitian dengan SPSS. Yogyakarta: Gava Media.

Rivai, Veithzal. (2005). Manajemen Sumber Daya Manusia untuk Perusahaan dari Teori ke Praktik, (Edisi Satu Cetakan Dua). Jakarta: PT Raja Grafindo Persada.

Rivai, Veitzhal., \& Ella Jauvani Sagala. (2009). Manajemen sumber daya manusia untuk perusahaan: dari teori ke praktik. Jakarta: Rajawali Persada.

Safitri, Erma. (2013). Pengaruh pelatihan dan disiplin kerja terhadap kinerja karyawan. Jurnal Ilmiah Manajemen, 1(4), 1044-1054.

Sarwono, Jonathan. (2007). Analisis Jalur untuk Riset Bisnis dengan SPSS. Yogyakarta: Penerbit Andi.

Sekaran, Uma. (2006). Metodologi Penelitian untuk Bisnis (Edisi 4, Buku 1). Jakarta: Salemba Empat.

Setiyono, Budi., \& Admojo, Tri. (2014). Pemerintahan dan manajemen sektor publik. Yogyakarta: CAPS.

Sugiyono. (2010). Metode Penelitian Pendidikan Pendekatan Kuantitatif, kualitatif, dan $R \& D$. Bandung: Alfabeta.

Vonny, Ratag Pingkan Elisabeth. (2016). Pengaruh Pelatihan, Fasilitas Kerja dan Kompensasi terhadap Kepuasan Kerja Karyawan pada PT United Tractors Cabang Manado. Jurnal Berkala Ilmiah Efisiensi, 16(03), 407-418. 
Wiludjeng, Sri. (2007). Pengantar manajemen edisi pertama. Yogyakarta: Graha Ilmu.

Yuliati, Sri. (2009). Pengaruh motivasi dan pelatihan terhadap kinerja karyawan politeknik pratama mulia Surakarta. Politeknosains, VIII(2), 20-31. 